\title{
Evaluation of the Production, Quality of Three Cultivars of Rhodes Grass (Chloris Gayana) and Viability of Seeds, Introduced in the Pampas
}

\author{
Sacido Mónica and Cicetti Gabriel \\ Forages Production Departament, Faculty of Agricultural Sciences, National University of Rosario, Zavalla 2123, Argentina
}

\begin{abstract}
This paper describes how a research was carried out about Chloris gayana Kunth. The objective of the work was to agronomical characterize the best sowing date, establishment efficiency, first year management, persistence strategies, biomass production and seeds. The parameter evaluated was: morphological, quality and production of seeds of three commercial cultivars (Santana, Finecut and Recleimer). Trial duration is December 2012 to December $2016\left(33^{\circ} \mathrm{S}, 61^{\circ} \mathrm{W}\right)$ Argentina. Design three random blocks with three repetitions, plot $5 \times 5$ meter. The results were analyzed by ANOVA (Analysis of Variance), and there was used Tukey Test $(p<0.05)$ for comparison of averages, to determine significant differences between the different ones that will be sown. It was determined that the ends of spring dates ensure better establishment. Although the data of morphology of the first year (length of pod, length of blade and number of leaves/plant) presented differences between the cv, they did not mark a tendency that ensures the best development of one. Recleimer with 598 and 1,026 accumulated degree days present the highest values in both measurements. The accumulation of biomass over the years shows that commercial cv show a very similar performance $(12,000 \mathrm{~kg}$ DM (Dry Matter) per hectare per year). The annual accumulation of DM would not vary significantly as monthly cuts are applied during the growing season or total accumulation without cuts would be allowed. In relation to quality parameters (gross protein, neutral detergent fiber and acid detergent fiber), Recleimer has the lowest values. Santana and Finecut were best in quality. Production of the seed was highest in May for all cvs. However, viability was limited in all date but Finecut and Recleimer showed best performance. As expected, in the megathermal species, seed production being one of the critical points.
\end{abstract}

Key words: Megathermal, quality, C4 (Carbon 4).

\section{Introduction}

Livestock in Argentina is basically pastoral and develops in a series of forage resources such as perennial pastures C3 and C4 (Carbon 3 and Carbon 4), winter and summer crops, natural pastures and reserves. There is a strong interdependence between the soil, the pastures and the animals, which determines the complexity of the livestock systems [1]. It's necessary to evaluate the potential and management conditions of implanted grasslands and forage that are compatible with the sustainability of the productive systems [2]. Myers, N. [3] established the main cause of the degradation of tropical and

Corresponding author: Sacido Mónica, Ph.D., research field: agronomic engineering. subtropical pastures, changes in chemical composition and low water uptake by modifications in physical composition of the soil (structure). Because of this, there is an interest in analyzing the chemical condition (OM (Organic Material), N, P and pH). The statement indicates therefore the importance of evaluating frequency, coverage, total dry matter production, by components and crude protein. Approximately 14\% (about 33 million hectares) of the total area of Argentina has salinity problems while about 8\% (18 million hectares) corresponds to sodic soils [4]. The salinity of the soil produces a negative effect on the growth of the non-tolerant crops, generating a decrease in the yield. This translates into alterations in morpho-physiological characters, which are those that are visually appreciated when the crop is subjected to 


\section{Evaluation of the Production, Quality of Three Cultivars of Rhodes Grass (Chloris Gayana) and Viability of Seeds, Introduced in the Pampas}

saline conditions [5]. The tolerance to the salts can be different according to the stage of the plant (seed, seedling and adult plant) [6]. The sowing of megathermic species in saline environments of the depressed pampa has allowed increasing the primary productivity with respect to the natural pasture or rangeland [7]. The sowing of megathermic pastures, as well as the multiplication and commercialization of seed, have a relatively short history at world-wide level being one of the biggest challenges to obtain the production of seeds with high viability to obtain a suitable implantation. According to Cicetti, G. [8], differences were detected by date for seed yield.

Chloris gayana Kunth (Rhodes grass) is forage that adapts and produces in saline-alkaline soils and is plastic in different climate conditions, from subtropical to temperate. In its genetic diploid form, it is incorporated to the cattle fields of the Argentine northwest since 1917, being the cultivated forage that occupies more surface, presents a content of crude protein of $5.25 \%$ and a digestibility of $43 \%$ (both in dry base), as reported by Ricci, H. R. [9]; while Peuser, R. [10] cites metabolizable energy values of $1.7 \mathrm{M}$ cal per $\mathrm{kg}$ of DM, sugars and starch less than $100 \mathrm{~g} / \mathrm{kg}$ of DM and high levels of lignified fiber. Comparative trials between tropical grasses, determine that their behavior as deferred forage is better than that of Panicum maximun Jack cv Gatton and that of Cenchrus ciliaris Link cvs Texas and Biloela, to maintain a greater amount of green tissue during the winter months. Analyzing the winter dynamics of deferred tropical pastures, found that in the case of Rhodes grass diploid, the deferred dry material suffers over time a significant natural discharge with qualitative and quantitative losses, leaving by the end of August a remnant that represents $48 \%$ of the initial material.

Thermal summation time is a measurement tool that allows estimating the growth rate of pastures. In recent years it has been used as a unit of measurement to express results, because it allows extrapolation of information to other places with different thermal conditions [11]. Each species has a minimum temperature below which it does not grow, for example $13{ }^{\circ} \mathrm{C}$, Chloris gayana [12]. In addition, rainfall during the period should be considered, since it may happen that the corresponding stages of development have been met, but growth (availability of forage) is not sufficient to achieve grazing [13]. According to Agnusdei, M. [14], to achieve a high efficiency of production and use of pastures, strategies must be defined for harvesting and management, aimed at harvesting the plant material before the aging and death of the first fully expanded leaf, which appeared later, occurs to the last grazing. The quality of the forage resource, in green or deferred, is markedly different in terms of $\%$ protein, digestibility or fiber, being higher in the first case. These quality differences translate into different nutrient inputs per $\mathrm{kg}$ DM consumed and at different levels of deferred intake, which further affects production per animal per ha. [15].

The objective of the work was to agronomically characterize the best sowing date, establishment efficiency, first year management, persistence strategies, biomass production and seeds of Chloris gayana Kunth (Rhodes grass).

\section{Material and Methods}

Trial duration: December 2012 to December 2016. Location: National University of Rosario, Faculty of Agricultural Sciences, J. F. Villarino experimental field, Zavalla, Santa $\mathrm{Fe}\left(33^{\circ} \mathrm{S}, 61^{\circ} \mathrm{W}\right)$, belongs to the Pampean plain and within it, the undulating Pampa. The climate of the region is characterized by being subhumid, mesothermal, with a variable annual rainfall pattern, from 600 to $1,200 \mathrm{~mm}, 70 \%$ occurs from September to March. Average annual temperature is $16{ }^{\circ} \mathrm{C}$, the average temperature in January is $24{ }^{\circ} \mathrm{C}$, July average is $9{ }^{\circ} \mathrm{C}$. The maximum temperatures of January are registered in the order of $3{ }^{\circ} \mathrm{C}$ and the minimal temperatures of January in 
$16{ }^{\circ} \mathrm{C}$. For the month of July, the maximum is recorded at $16{ }^{\circ} \mathrm{C}$ and the minimal at $4{ }^{\circ} \mathrm{C}$. Frost regime has a distribution from the month of May to September, with a greater frequency in the months of June, July and August. The region suffers from the occurrence of late frosts in the months of October, November and early in the months of April [16]. The following data was collected by the meteorological station of the Faculty of Agricultural Sciences, and data are presented three months prior to planting and three months after the last planting.

The trial was set up on a flat soil type Argiudol Vértico. Chemical analysis was performed. The samplings were carried out randomly at $20 \mathrm{~cm}$ depth by using a drill hole, 3 composite samples $(\mathrm{N}, \mathrm{P}, \mathrm{OM}$ and $\mathrm{pH}$ ). The determinations were made before sowing the species in July, 2012 (initial condition). The values are presented in Table 2.

Treatment:

First objective: to determine the optimum sowing dates for the species Chloris gayana Kunth (Rhodes grass), an experiment was designed with three commercial cultivars (Santana, Finecut and Recleimer) and three sowing dates December 10, 2012, December 20, 2012 and January 20, 2013.

Design three random blocks with three repetitions, plot $5 \times 5$ meter.

The aspects to be evaluated were: number of plants implanted 60 days after implantation and morphological characterization.

Number of plants: an iron frame of $0.10 \mathrm{~m}^{2}$ was used, randomly throwing in each plot 3 times.

Height of the plants: a ruler graduated in centimeters was used, taking as an upper reference the last expanded sheet, of several plants representative of the sampling point.

Length of sheets: rule graduated in millimeters was used, taking as reference the insertion of the sheath as starting point of the sheet.

Length of pods: a graduated rule in millimeters was used, taking as reference the insertion in the node as starting point of the pod until the insertion of the sheet.

The analysis of means and deviations corresponding to each treatment was performed.

According to the results obtained in the first year, in November 14 of 2013, a new sowing of the batch prepared in a conventional manner was carried out, chemical control with glyphosate $2 \mathrm{~L} \cdot \mathrm{ha}^{-1}$, and broadcasting with a density of $4.5 \mathrm{~kg} \cdot \mathrm{ha}^{-1}$ sowing with three commercial cultivars (Santana, Finecut and Recleimer).

Design Three Random blocks with three repetitions, plot $5 \times 5$ meter.

Two phenological stages: (1) panicle not expanded and (2) panicle expanded, for each date, to have the representative mean of the plot.

The parameters to be evaluated were: plant height, number of plates and tillers per plant.

Table 1 Rainfall and average relative air humidity in the influential months to the sowing (2012-2013).

\begin{tabular}{lllllllll}
\hline & Sep. & Oct. & Nov. & Dec. & Jan. & Feb. & Mar. & Apr. \\
\hline Rainfall (mm) & 93.8 & 307 & 98.3 & 244 & 31 & 73.7 & 36.2 & 36 \\
Average relative air humidity (\%) & 80 & 83 & 76 & 78 & 75 & 83 & 81 & 77 \\
\hline
\end{tabular}

Table 2 Chemical parameters.

\begin{tabular}{ll}
\hline Parameters & Average \\
\hline \% of carbon (Walkley-Black's method) & 1.7 \\
\% of organic matter (Walkley-Black's method) & 2.99 \\
p.p.m. of nitrates (Harper's method) & 38.59 \\
p.p.m. of removable phosphorus (Bray-Kurtzl's method) & 36.63 \\
pH in water $(1: 2.5)$ (Electrometric method) & 5.69 \\
Electrical conductivity $(1: 2.5)(\mu \mathrm{mhos} / \mathrm{cm})$ & 0 \\
$\%$ humedity (Gravimetric method) & 7.86 \\
\hline
\end{tabular}


Height of the plants: a ruler graduated in centimeters was used, taking as an upper reference the last expanded sheet, of several plants representative of the sampling point.

Number of tillers per plant: in tillers chosen according to Matteucci, S. [17], a metal frame of 0.1 $\mathrm{m}^{2}$ was used. Within each one, the number of tillers per plants was counted.

Number of sheets per plant: A metal frame of 0.1 $\mathrm{m}^{2}$ was used, tossing it randomly 3 times per plot, the plants found therein were separated and the number of leaves of each was counted.

Number of plants: an iron frame of $0.1 \mathrm{~m}^{2}$ was used, randomly throwing in each plot 3 times.

Number of stolons per plant: an iron grid of $0.1 \mathrm{~m}^{2}$ with internal divisions of $10 \mathrm{~cm} \times 10 \mathrm{~cm}$ was used to facilitate the division of the plants and the measurement of the number of stolons.

Coverage: determined by the Braun-Blanquet, J.'s [18] method.

Aerial biomass: an iron frame of $0.1 \mathrm{~m}^{2}$ was used, cutting with scissors the pasture, leaving a remnant of $10 \mathrm{~cm}$ in height, and collecting all the brush that was deposited on the ground. Their weight was determined in fresh and dry, using precision balance in the laboratory. The green material was separated from the dead material and its fresh weights recorded. Then the green material was taken to drying oven at a temperature of $65{ }^{\circ} \mathrm{C}$ until constant weight, this observation was used to determine the percentage of dry matter of the pastures and the total biomass accumulated in $\mathrm{DM} \cdot \mathrm{Ha}^{-1}$.

Nutritional quality: a representative fraction of the samples obtained in each treatment was sent to the laboratory to carry out chemical analyzes of nutritional quality. Dry matter grams plant [19], ADF (Acid Detergent Fiber) and NDF (Neutral Detergent Fiber) [20], nitrogen and protein (the laboratory analyzes were made following the protocol proposed by the proximal analysis according to AOAC standards), determining the crude protein concentration (CP) from the determination of total $\mathrm{N}$ by semi-micro Kjeldahl analysis by distillation-titration multiplied by the factor 6.25 , the result was expressed as a percentage on a dry basis [21].

Number of seeds: traps were used that consist of a vertical iron structure covered by a lycra mesh to which two rings of the same diameter are attached at a distance between them of $30 \mathrm{~cm}$ containing a funnel collector of seeds at the base of the second ring. The inflorescences were incorporated into the trap by means of a groove made on the funnel, maintaining the natural conditions of the funnel as much as possible. In each block, 2 traps were placed with 3 inflorescences each counting the total number of seeds collected in each sample. The traps were placed on March 1.

Number of seeds filled: the number of seeds, seeds previously selected for brightness and turgor, external characteristics of viable seeds was determined by means of a magnifying glass [22].

Total viability: the seeds were analyzed, under the ISTA (International Seed Testing Association) methodology to determine the total viability (viability determined on $\%$ of full seeds) [23].

Design Random blocks with three repetitions.

The results were analyzed by ANAVA, and the Tukey Test $(p<0.05)$ was used to compare means, to determine significant differences between the different cultivars, the different thermal accumulations and the possible interactions in all years. The statistical used package was the Info Stat version 9.0 [24].

\section{Results and Discussion}

For the first seeding date, the five days prior to it had an average humidity of $85 \%$, which continued for six more days. On the second date, the previous five days showed an $85 \%$ moisture situation that decreased to $75 \%$ for 7 more days. For the third planting date the values were close to $65 \%$. These different conditions affected the implementation, which could be observed 
on March 4, 2013 when the evaluations were made. For the first date of planting, the largest number of plants $/ \mathrm{m}^{2}$ was presented by Santana with 34 plants $/ \mathrm{m}^{2}$, for the second date the best were Recleimer and Finecut, with 17 plants $/ \mathrm{m}^{2}$, in the third only Santana germinated with 89 plants $/ \mathrm{m}^{2}$.

In the sampling of April 18, 2013, there were no significant differences in plant height between Santana and Finecut $(79 \mathrm{~cm})$ and yes with Recleimer $(15 \mathrm{~cm})$. In relation to pod length, length of leaf and number of leaves/plant were the parameters that showed the most differences between cultivars. In the film width, there were no differences between Recleimer and Santana $(0.5 \mathrm{~cm})$ and yes with Finecut $(0.8 \mathrm{~cm})$. In the third evaluation on June 13, 2013, only Santana and Finecut persisted. Plant height and blade width did not show significant differences between the two cultivars, Santana $(78 \mathrm{~cm}-0.5 \mathrm{~cm})$, Finecut $(76.7$ $\mathrm{cm}-0.61 \mathrm{~cm}$ ).

There were differences between cultivars in relation to the length of the blade and the length of the pod, Santana has the longest pod length of $14.65 \mathrm{~cm}$ vs 8.8 $\mathrm{cm}$ of Finecut and the blade length was greater in Finecut $15.85 \mathrm{~cm}$ vs $10.5 \mathrm{~cm}$ from Santana.

Describe morphologically and through quality parameters three cultivars of Chloris gayana (Rhodes grass).

Sixty days after sowing, the number of plants $\mathrm{m}^{-2}$ was determined, with an average value of 134 plants $\mathrm{m}^{-2}( \pm 4.94 \mathrm{SD})$ of the $3 \mathrm{cv}$.

In a second count, 120 days after sowing, 105 $\mathrm{pl} \cdot \mathrm{m}^{-2}$ were found in the Recleimer $\mathrm{cv}, 116$ plants $\cdot \mathrm{m}^{-2}$ in Santana and 120 plants $\cdot \mathrm{m}^{-2}$ in Finecut, without being statistically different.

When comparing the behavior of the different cultivars in the different dates, two possible comparisons emerge, the differences that are related to the difference of accumulated days degrees for each cultivar and the difference between cultivars within a same thermal time.

With 598 accumulated degree days, Finecut accumulated the least DM (18\% above), coinciding with Cicetti, G. [25], Recleimer and Santana were with the highest biomass.

With 1,026 accumulated degree days, Recleimer had the highest aerial biomass (20\% above), with respect to another cv.

With 1,026 accumulated degree day or base temperature, the average of the cultivars presents on average 39\% more accumulation of DM, as observed in Table 2, which accumulated in 598 days. Regarding the number of sheets per plant, the second date presented around $31 \%$ more than the first, and Recleimer continues with the tendency to present the highest values in both measurements, differing widely from Santana and Finecut. The number of tillers per plant, although no significant differences, is not unrelated to this behavior, and presented $9 \%$ more on the second date, in the same way Recleimer showed the highest values compared to other cultivars.

As shown in Table 3, plant height differs significantly between different dates, but not between cultivars.

The average values of Protein, Neutral Detergent Fiber, Acid Detergent Fiber and Nitrogen are presented as quality indicators in Table 5.

Table 3 High morphological parameters, according to species and thermal time.

\begin{tabular}{lllll}
\hline Acumulated degree day & Species & $\begin{array}{l}\text { Average number of } \\
\text { sheets for plants }\end{array}$ & Average height (cm) & $\begin{array}{l}\text { Number of tillers per } \\
\text { plant }\end{array}$ \\
\hline 1,026 & Recleimer & A 71.33 & a 107.43 & $a 9.17$ \\
1,026 & Finecut & AB 46.83 & a 105.92 & $a 6.50$ \\
1,026 & Santana & AB 44.17 & a 90.58 & $a 6.83$ \\
598 & Recleimer & AB 50.17 & b 66.50 & $a 8.33$ \\
598 & Santana & AB 35.50 & b 59.17 & $a 5.67$ \\
598 & Finecut & B 27.50 & b 61.33 & $a 6.33$ \\
\hline
\end{tabular}

Averages for column with a different letter are significantly different $(p<0.05)$. 
Table 4 Dry matter per plant and quality parameters.

\begin{tabular}{llllll}
\hline $\begin{array}{l}\text { Degree } \\
\text { days }\end{array}$ & Cultivar & $\begin{array}{l}\text { Dry matter } \\
\left(\mathrm{g} \cdot \text { plant }^{-1}\right)\end{array}$ & $\begin{array}{l}\text { Protein } \\
(\%)\end{array}$ & $\begin{array}{l}\text { NDF } \\
(\%)\end{array}$ & $\begin{array}{l}\text { ADF } \\
(\%)\end{array}$ \\
\hline 598 & Recleimer & $4.50 \mathrm{ab}$ & $7.06 \mathrm{a}$ & $48.03 \mathrm{a}$ & $38.17 \mathrm{a}$ \\
598 & Finecut & $2.83 \mathrm{~b}$ & $8.31 \mathrm{a}$ & $42.77 \mathrm{~b}$ & $32.81 \mathrm{bc}$ \\
598 & Santana & $6.17 \mathrm{ab}$ & $8.94 \mathrm{a}$ & $44.70 \mathrm{ab}$ & $33.33 \mathrm{bc}$ \\
1,026 & Recleimer & $10.17 \mathrm{a}$ & $8.46 \mathrm{a}$ & $46.47 \mathrm{ab}$ & $36.12 \mathrm{ab}$ \\
1,026 & Finecut & $8.83 \mathrm{ab}$ & $8.54 \mathrm{a}$ & $46.57 \mathrm{ab}$ & $32.16 \mathrm{c}$ \\
1,026 & Santana & $5.83 \mathrm{ab}$ & $8.31 \mathrm{a}$ & $45.79 \mathrm{ab}$ & $33.83 \mathrm{bc}$ \\
\hline
\end{tabular}

Averages for column with a different letter are significantly different $(p<0.05)$.

Table 5 Quality parameters.

\begin{tabular}{lllll}
\hline $\mathrm{CV}$ & $\begin{array}{l}\text { Nitrogen } \\
(\%)\end{array}$ & $\begin{array}{l}\text { Protein } \\
(\%)\end{array}$ & $\begin{array}{l}\text { NDF } \\
(\%)\end{array}$ & $\begin{array}{l}\text { ADF } \\
(\%)\end{array}$ \\
\hline Santana & $1.38 \mathrm{a}$ & $8.63 \mathrm{~A}$ & $45.24 a$ & $33.58 \mathrm{~A}$ \\
Finecut & $1.35 \mathrm{a}$ & $8.41 \mathrm{~A}$ & $42.96 b$ & $31.97 \mathrm{~A}$ \\
Recleimer & $1.24 \mathrm{~b}$ & $7.75 \mathrm{~B}$ & $47.24 a$ & $37.13 \mathrm{~B}$ \\
\hline
\end{tabular}

Averages for column with a different letter are significantly different $(p<0.05)$.

After performing statistical analyzes on the values, in NDF and ADF protein (Tukey Test $(p<0.05)$ ), the cultivar Santana, Finecut and Recleimer, the last one having the lowest nutritional value can be differentiated significantly. The Protein values reported by Duhalde, A. J. [26] of $8.4 \%$ in the cv Pionner, are similar to the values of these commercial cvs and are within the parameters expressed by Calsina, M. [27] of $7.5 \%$ and $9 \%$ of Protein. The values of ADF were found by Pesquiera, J. [28], 35\% \pm 1.7 similar, but did not coincide with protein $5.63 \%$ \pm 0.46 and NDF $66.1 \% \pm 1.51$.

In relation to the number of stolons, they can be related to the density of plants (Table 6) since to smaller number of plants found the greater number of stolons, nevertheless no significant differences are found (Tukey Test $(p<0.05)$ ) between cultivars in both parameters.

In addition, significant differences can be observed between the cultivars in relation to the coverage. It can be observed that the Finecut $\mathrm{cv}$ has a higher basal coverage, given by a greater number of plants, although no significant differences were found in the $5 \%$ ANOVA test in the number of plants, if such differences were found with respect to coverage.

Fig. 1 shows the $\mathrm{kg}$ of biomass accumulated by the different cv throughout the year, as total biomass and is discriminated between the regrowth biomass of the spring of 2014 and the dry biomass generated in the summer-previous autumn. No significant differences were found among the cultivars, but parity was found in the production of forages among the $3 \mathrm{cvs}$.

As can be seen, the sum of the dry biomass and regrowth biomass of that was measured in the month of November, after accumulating throughout the year, does not present statistical differences between the different cultivars, being $11,900 \mathrm{~kg} \mathrm{DM} \cdot \mathrm{Ha}^{-1}$ for the cv Finecut, 11,500 $\mathrm{kg} \mathrm{DM} \cdot \mathrm{Ha}^{-1}$ for the $\mathrm{cv}$ Santana and $11,200 \mathrm{~kg} \mathrm{DM} \cdot \mathrm{Ha}^{-1}$ for the $\mathrm{cv}$ Recleimer.

These values are practically similar to those found as the sum of the monthly production shown in Table 8. Here, have to take into account the behavior of the species against monthly defoliation or closure for a deferred use, although the quality in both cases will be different.

The frequency of defoliation and the duration of the period of deferral are related to the quality of the forage. Low frequency of defoliation and high duration of the period of deferral reduce the concentration of sheet and brute protein, increasing the total biomass and the concentration of fiber (cellular wall) of the forage. 

of Seeds, Introduced in the Pampas

Table 6 Mean number of plants for $\mathrm{m}^{2}$; number of stolons for $\mathrm{m}^{2}$ and \% soil cover.

\begin{tabular}{llll}
\hline $\mathrm{CV}$ & Number of plants $\cdot \mathrm{m}^{-2}$ & Number of stolons $\cdot \mathrm{m}^{-2}$ & Basal coverage $\%$ \\
\hline Finecut & $95.00 \mathrm{a}$ & $0.83 \mathrm{a}$ & $55.00 \mathrm{~b}$ \\
Santana & $88.33 \mathrm{a}$ & $0.77 \mathrm{a}$ & $36.67 \mathrm{a}$ \\
Recleimer & $76.76 \mathrm{a}$ & $0.79 \mathrm{a}$ & $35.83 \mathrm{a}$ \\
\hline
\end{tabular}

Averages for column with a different letter are significantly different $(p<0.05)$.

Table 7 Mean number of plants for $\mathrm{m}^{2}$; number of stolons for $\mathrm{m}^{2}$ and $\%$ soil cover.

\begin{tabular}{llll}
\hline CV & Number of plants $\cdot \mathrm{m}^{-2}$ & Number of stolons $\cdot \mathrm{m}^{-2}$ & Basal coverage $\%$ \\
\hline Finecut & $95.00 \mathrm{a}$ & $0.83 \mathrm{a}$ & $55.00 \mathrm{~b}$ \\
Santana & $88.33 \mathrm{a}$ & $0.77 \mathrm{a}$ & $36.67 \mathrm{a}$ \\
Recleimer & $76.76 \mathrm{a}$ & $0.79 \mathrm{a}$ & $35.83 \mathrm{a}$ \\
\hline
\end{tabular}

Averages for column with a different letter are significantly different $(p<0.05)$.

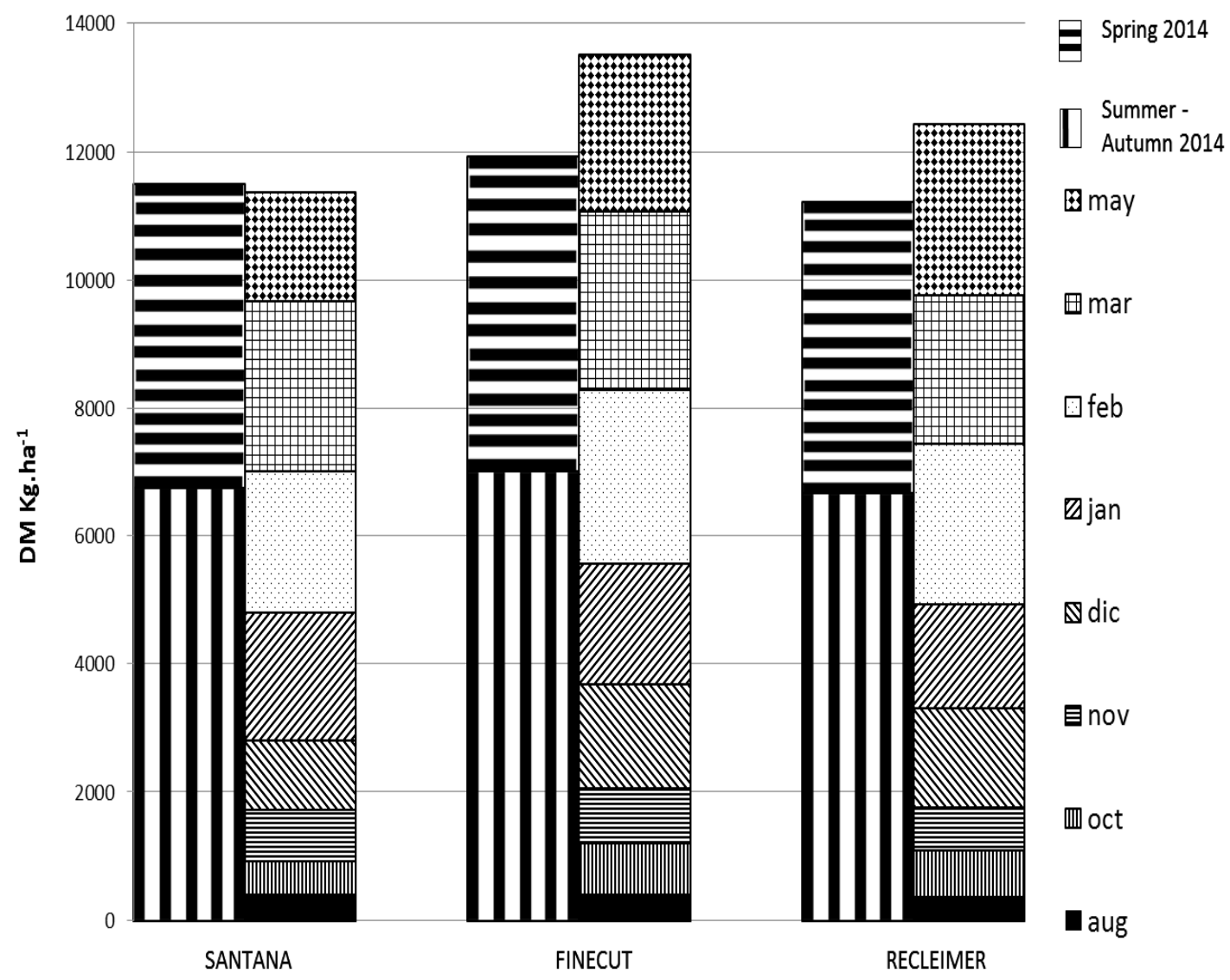

Fig. 1 Comparison of production of biomass for cut and annual production $\left(\mathrm{DM} \mathrm{kg} \cdot \mathrm{Ha}^{-1}\right)$.

These modifications in the vegetable structure, strike directly on the animal response, diminishing the indexes of production, so much individual as for unit of area [29].

The maximum and minimal temperatures from June 2015 to May 2016 are shown below, with the corresponding precipitations, obtained from the meteorological station of the faculty.

In Fig. 1, the accumulated biomass of the three cultivars throughout the different months of production can be observed, where the first cut is made at the end of winter and at intervals of approximately 38 days, highlighting that, in the month of April a storm occurred throughout the month with constant rainfall. 
Table 8 Rainfall (mm), maximum and minimal temperatures $\left({ }^{\circ} \mathrm{C}\right)$.

\begin{tabular}{llll}
\hline Month & Maximum temperatures $\left({ }^{\circ} \mathrm{C}\right)$ & Minimal temperatures $\left({ }^{\circ} \mathrm{C}\right)$ & Rainfall $(\mathrm{mm})$ \\
\hline Jun.-15 & 19.5 & 6.5 & 20.6 \\
Jul.-15 & 17.9 & 4.8 & 47.5 \\
Aug.-15 & 18.8 & 8.8 & 138.4 \\
Sep.-15 & 19.7 & 7.6 & 11.5 \\
Oct.-15 & 21.7 & 10.7 & 87.9 \\
Nov.-15 & 26 & 14.3 & 107.2 \\
Dec.-15 & 30.2 & 20.2 & 56.8 \\
Jan.-16 & 30.8 & 18.2 & 110.6 \\
Feb.-16 & 30.2 & 17.4 & 236.3 \\
Mar.-16 & 26.3 & 14 & 48.5 \\
Apr.-16 & 21.3 & 13 & 238.7 \\
May-16 & 18.3 & 77 & 0 \\
\hline
\end{tabular}

Table 9 Kilograms of DM per hectare per $\mathrm{cv}$ in the different cuts $\left(\mathrm{DM} \mathrm{kg} \cdot \mathrm{Ha}^{-1}\right)$.

\begin{tabular}{llllllllll}
\hline cv & 28-Aug. & 05-Oct. & 07-Nov. & 02-Dec. & 09-Jan. & 12-Feb. & 23-Mar. & 02-May & Total \\
\hline Santana & 400 & 527 & 807 & 1,067 & 2,001 & 2,225 & 2,647 & 1,707 & 11,500 \\
Recleimer & 400 & 807 & 860 & 1,617 & 1,894 & 2,717 & 2,783 & 2,437 & 11,200 \\
Finecut & 360 & 727 & 673 & 1,560 & 1,611 & 2,525 & 2,323 & 2,663 & 11,900 \\
\hline
\end{tabular}

The highest values of $\mathrm{kg} \mathrm{DM} \cdot \mathrm{Ha}^{-1}$ found in January, February and March, for the three cvs agrees with that found by Cicetti, G. [30], in a locality near the experimental site, being 2,000 $\mathrm{kg} \mathrm{DM} \cdot \mathrm{Ha}^{-1}$ approximately the values of these months, and of 500 $\mathrm{kg} \mathrm{DM} \cdot \mathrm{Ha}^{-1}$ the values found in the month of August.

The production of aerial biomass responds to the thermal variation of the different months, this is reflected in the Fig. 2, which shows the evolution of the daily growth rate of the different $\mathrm{cv}$ over the months related to the accumulation daily thermal, using as a base temperature $12{ }^{\circ} \mathrm{C}[31]$.

The typical behavior of a production rate of a $\mathrm{C} 4$ grass can be observed, where in December it differs due to the lower amount of rainfall that occurred in that month, compared to the historical average (120.6 $\mathrm{mm}$ ) [32]. There are evidences that show that the hydric state of the plant can limit leaf expansion rates during periods with high evapotranspiration demand associated with water deficit in the soil [33].

The analysis of Pearson's linear simple correlation (Table 10) reveals that the accumulated biomass correlates positively and significantly with the rainfall and degree days, nevertheless, the adjustment is major with degree days, with regard to rainfall, being the variable that explains, in average, in $84 \%$ of the variation, vs $62 \%$.

With relation to the production of seeds there were no significant differences beetwen cvs, but significant differences (Tukey Test $(p<0.05)$ ) were found in the production of seed in the different dates, of May with regard to March with a $\mathrm{R}^{2}$ 0.79. The production of seeds was superior to 12 weeks after the cut, since cut was realized on February 10th as can be seen in Fig. 3. The ideal moment of crop, according to Boonman, J. C. [34], being employed at Setaria and Chloris is 42-49 days; nevertheless, in Israel, Gordon Shaus, A. and Gilmond, H. [35], they thought that Chloris's seeds, harvested to 45 days were containing too many unripe seeds and raised that the harvested ones in an interval of 60-70 days provided better viability, as well as spiculs with a major content of cariopsis. These discrepancies as for the determination of the ideal moment of crop confirm that the processes of flowering and ripeness are controlled by the environmental conditions and other factors (fertilization, irrigation, invasion of thickets and maximum moment of flowering) specifics of every place. 


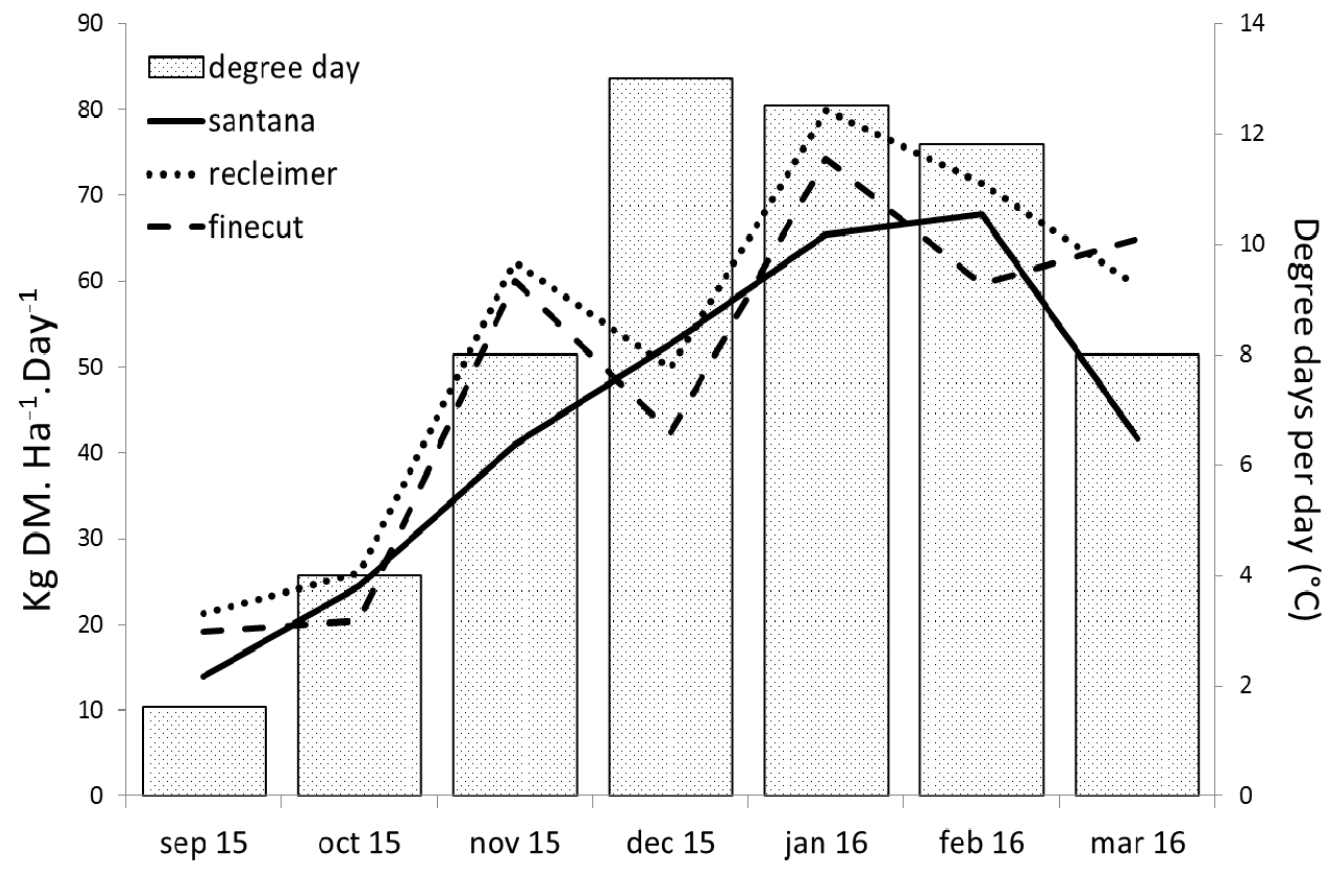

Fig. 2 Daily rate of growth $\left(\mathrm{DM} \mathrm{kg} \cdot \mathrm{Ha}^{-1} \cdot \mathrm{Day}^{-1}\right)$ per $\mathrm{cv}$ and acumulated degree days per days $\left({ }^{\circ} \mathrm{C}\right)$.

Table 10 Coefficient of linear simple regression among the yield of biomass for $\mathrm{cv}$ and rainfalls and degrees accumulated days.

\begin{tabular}{lll}
\hline Santana biomass yield versus & $\mathrm{r}$ & Significance level \\
\hline Rainfall & 0.67 & $8.30 \mathrm{E}-04$ \\
Degree day & 0.91 & $9.60 \mathrm{E}-09$ \\
Finecut biomass yield versus & $\mathrm{r}$ & \\
Rainfall & 0.5 & $2.00 \mathrm{E}-02$ \\
Degree day & 0.72 & $2.20 \mathrm{E}-04$ \\
Recleimer biomass yield versus & $\mathrm{r}$ & \\
Rainfall & 0.6 & $3.70 \mathrm{E}-03$ \\
Degree day & 0.77 & $3.80 \mathrm{E}-05$ \\
\hline
\end{tabular}

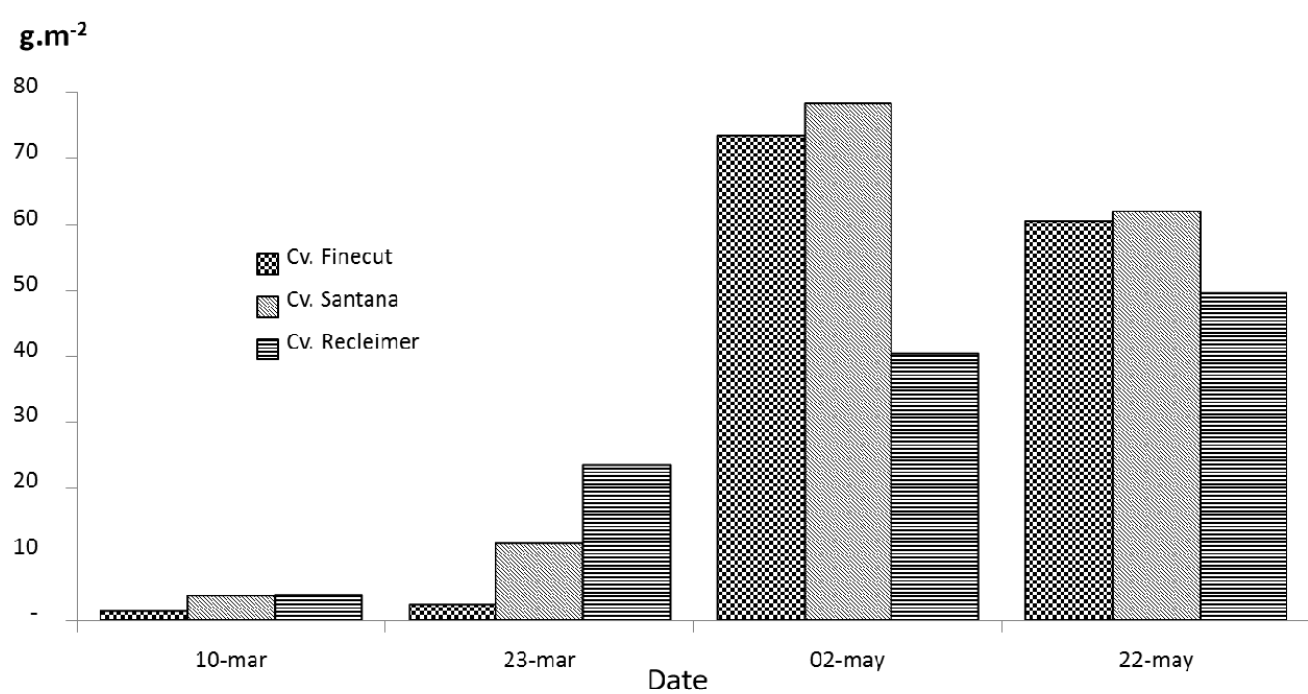

Fig. 3 Seed production per $\mathrm{cv}$ in a cycle of production $\left(\mathrm{g} \cdot \mathrm{m}^{-2}\right)$. 
It is possible to observe that the crop of May presents the major values, continuing the idea that expresses Bilbao, B. [36], that as the crop slow down, the production increases, which agrees with Boonman, J. C. [34] being employed at Chloris and Strickland, R. W. [37] and Padilla, C. and Febles, G. at the gender Panicum [38].

There were no significant differences with regard to the total viability. It is necessary to inform that the sample corresponding to April 10th discarded for temporarily rains that the loss of the same one caused. It is necessary to emphasize that the percentage of complete seeds does not overcome $10 \%$ for the different dates of sampling, but if they found differences between CV, being Santana (5.83\%) that of minor percentage, with regard to Finecut $(10.50 \%)$ and Recleimer $(9.17 \%)$. As for the total viability for $\mathrm{cv}$, Finecut (10.50\%) and Recleimer (8.83\%) difference significantly of Santana with an average value of $5.67 \%$.

\section{Conclusions}

It was determined that the earliest dates ensure better implementation, since it was observed that the later dates for planting Chloris gayana Kunth had lower efficiency in implementation, possibly less moisture available in the environment (lower moisture superficial portion of the soil).

Based on these results, sowing was carried out in the month of November, here there is a notable increase in the number of plants that were implanted, advancing the sowing date.

The data of morphology of the first year (length of pod, length of blade and number of leaves/plant) although they presented differences between the cv, did not mark a tendency that ensures the best development of one.

Recleimer with 598 and 1,026 accumulated deegre days present the highest values in both measurements.

The Finecut $\mathrm{cv}$ has a higher basal coverage given by a greater number of plants, and the Recleimer cv, the smaller coverage, fewer plants but the greater number of stolons, determining that the density of plants modifies the invasive capacity of the species. This aspect could be used according to the objective of implantation of the species; if it is to restore a site it would select the one that produces the largest amount of stolons.

The accumulation of biomass over the years shows that commercial $\mathrm{cv}$ show a very similar performance, without being able to determine the productive superiority of one over the others. The reported values are close to $12,000 \mathrm{~kg}$ DM per hectare per year.

The annual accumulation of DM would not vary significantly as monthly cuts are applied during the growing season or total accumulation without cuts would be allowed.

In relation to quality parameters, (gross protein and neutral detergent fiber and acid detergent fiber), Recleimer has the lowest values, Santana and Finecut were best in quality.

Production of the seed was higest in May for all cv. However, viability was limited in all date but Finecut and Recleimer showed best performance. As expected, in the megathermal species, seed production being one of the critical points.

\section{Reference}

[1] Barsky, O. 1988. The Agricultural Development Pampeano. Collection Political Social Studies. Buenos Aires: Latin-American Group.

[2] Morlacco, M. B. 2014. "Information Generated from the Information Presented by the Integrated System of Agricultural Information/Statistics/Agricultural Estimations. 2012-2013.” Accessed March 05, 2018. https://www.agroindustria.gob.ar/datosabiertos.

[3] Myers, N. 1989. Tropical Deforestation and Cllimatic Change. Climate and Geo-Sciences. Kluwer Academic Publishers, 341-53.

[4] National Institute of Agricultural Technology Rafaela. 2013. Megathermal Days. Technical report No. 58.

[5] Bennett, S. J., Barrett-Lennard, E. G., and Colmer, T. D. 2009. "Salinity and Waterlogging as Constraints to Salt Land Pasture Production: A Review." Agriculture, Ecosystems and Environment 129: 349-60.

[6] Munns, R, and James, R. A. 2003. "Screening Methods 


\section{Evaluation of the Production, Quality of Three Cultivars of Rhodes Grass (Chloris Gayana) and Viability of Seeds, Introduced in the Pampas}

for Salinity Tolerance: A Case Study with Tetraploid Wheat." Plant and Soil 253: 201-18.

[7] Otondo, J. 2011. "Effects of the Introduction of Megathermal Species on Agronomic Characteristics and Edáphics of an Environment Halomorphic of the Flood Pampas." M.Sc. thesis, Buenos Aires, Argentina, School for Graduates Facultad of Agronomy.

[8] Cicetti, G., Sacido, M., and Spiller, L. 2015. "Evaluation of Strategies of Persistence in the Year of Establishment of Three You will Cultivate of "Grass Rhodes" (Chloris Gayana) Introduced in the Pampas Region." In Proceedings of XXXVIIIth Congress of the Argentine Association of Animal Production.

[9] Ricci, H. R., and Guzman, L. P. 1992. "Effect of the Date of I Leave behind on the Production of Dry Matter, Availability and Winter Quality of the Deferred One from Grass Rhodes cv. Tuc La Oriental (Chloris gayana Kunth)." Magazine Industry and Agriculturalist of Tucumán 69 (1-2): 1-5.

[10] Peuser, R. 1994. Strategic Use of the Concentrate in Tropical Pastures, Days on Utilization of Tropical Pastures. GIPP-Tucumán, 16.

[11] Bertram, N., and Chiacchiera, S. 2011. The not Agricultural Environments of the Central Region and the Potential Fodder. Report of Technical Update. National Institute of Agricultural Technology.

[12] Durán, P. N., Ruiz, C. J. A., González E. D. R., Núñez H. G., Padilla R. F. J., and Contreras R. S. H. 2011. "Temperatures of Development in the Stage Sowing-Emergency of 11 Grasses Fodder." Mexican Magazine of Livestock Sciences 347-58.

[13] Ferri, C. M., Brizuela, M. A., Cid, M. S., and Stritzler, N. P. 2006. "Dynamics of Accumulation of Sheets You will Foliate and Structure of the Forage Deferred from Panicum coloratum L." Technical Agricultural (Chile) 66 (4): 76-384.

[14] Agnusdei, M., Nenning F. R., Dimarco, O., and Aello, M. 2009. "Variations of Nutritional Quality during the Vegetative Growth of Gramíneas Megathermal of Different Freightage and Length to Foliate. (Chloris gayana and Digitaria decumbens)." Argentine Magazine of Animal Production 29 (1): 13-25.

[15] Holgado, F. 1999. "Rural Development of Northwestern Argentine." INTA 18-24. http://www.produccionbovina.com.ar/produccion_y_man ejo_pasturas/pasturas_cultivadas_megatermicas/13-inver nada_sobre_la_base_de_pasturas_tropicales.pdf.

[16] National Meteorological Service. 1992. Climatological Statistics 1961-1990. Buenos Aires.

[17] Matteucci, S., and Colma, A. 1982. Methodology for the Study of the Vegetation. General Secretariat of the Organization of the American States. Regional Program of Scientific and Technological Development. Monograph $N^{\circ} 22$. Washington, DC.

[18] Braun-Blanquet, J. 1979. Phytosociological, Bases for the Study of the Vegetable Communities. Madrid: Blume Editions.

[19] A.O.A.C. 1990. Official Methods of Analysis. Association of Official Agricultural Chemistis, USA.

[20] COMCAL. 1987. Chemical and Chemical-Biological Evaluation of Forages. 1st edition. Balcarce, Argentina: EEA INTA.

[21] Van Soest, P., Robertson, J., and Lewis, B. 1991. "Methods for Dietary Fiber, Neutral Detergent Fiber and Nonstarch Polysaccharides in Relation to Animal Nutrition.” J. Dairy Sci. 74: 3583-97.

[22] Baskin, C. C., and Baskin, J. M. 1998. Biogeography and Evolution of Dormancy and Germination. Seed. Ecology. San Diego: Academic Press, 666.

[23] International Seed Testing Association. 2010. Internacional Rules for Seed Testing. CH-Switzerland: Basserdorf, 300.

[24] Di Rienzo, J. A., Casanoves, F., Balzarini, M. G., Gonzalez, L., Tablada, M., and Robledo, C. W. 2015. "InfoStat Statistical Software. InfoStat Group, Faculty of agrarian Sciences, National University of Córdoba, Argentina. URL." Accessed February 10, 2018. http://www.infostat.com.ar.

[25] Cicetti, G., Sacido, M., Spiller, L., 2014. "Evaluation of Strategies of Persistence in the Year of Implantation (Introduction) of Three You will Cultivate of "Grass Rhodes" (Chloris Gayana) Introduced in the Pampas Region." In Proceedings of the XXXVIIIth Congress of the Argentine Association of Animal Production.

[26] Duhalde, A. J., Perea, Z. A., Massigoge, A. J., Jensen, V. M., and Intaschi, A. D. 2010. Establishment and Production of Fodder Megathermal in the Buenos Aires South. Buenos Aires: National Institute of Agricultural Technology.

[27] Calsina, M., Mc Lean, G., Nenning, F., Otondo, J., Petruzzi, H., Pizzio, R., et al. 2014. "Fodder Grasses for the Subtropics and Central Semiarid of the Argentina." Accessed February 13, 2018. http://www.produccionbovina.com.ar/produccion_y_man ejo_pasturas/pasturas_cultivadas_megatermicas/213-Gra mineas_forrajeras_2014.pdf.

[28] Pesqueira, J., Otondo, J., and García, M. D. 2017. "Production of Biomass, Coverage and Quality Forrajera of Chloris gayana and Panicum coloratum in an Alkaline Sodium Soil of the Depression of the Salty One." Magazine of Agricultural Researches 43 (3): 231-8.

[29] Petruzzi, H. J., Stritzler, N. P., Adema, E. O., Ferri, C. M., and Pagella, J. H. 2003. "Everlasting Millets Panicum Coloratum." Accessed February 15, 2018. 
http://www.produccionanimal.com.ar/produccion_y_man ejo_pasturas/pasturas_cultivadas_megatermicas/09-mijo_ pernne.pdf.

[30] Cicetti, G., Formidabile, M., Zanini, B., Dupuy, J., and Sacido, M. B. 2014. "Relation Place with Productivity throughout the Year of "CV Pionee" (Chloris gayana) in the South of Santa Fe, Argentina." In Proceedings of the XXXVIIth Congress of the Argentine Association of Animal Production.

[31] Jones, C. A. 1985. C4 Grasses and Cereals: Growth, Development and Stress Response. New York: Wiley \& Sons.

[32] National Meteorological Service. Climatological Statistics 1971-2010. Buenos Aires.

[33] Munns, R., Passioura, J. B, Guo, J., Chazen, O., and Cramer, G. R. 2000. "Water Relations and Leaf Expansion: Importance of Time Scale.” J. Exp. Bot. 51: 1495-504.
[34] Boonman, J. C. 1971. "Experiment Studies on Seed Production of Tropical Grasses in Kenya. Tillering and Heading in Seed Crops of Eight Grasses." Noth. J. Agric. Sci. 19: 237.

[35] Gordon-Shaus, A., and Gilmond, H. 1966. "Seed Setting, Production and Viability of Rhodes Grass in Israel." East Afric. Agric. For. J. 31: 365.

[36] Bilbao, B., and Matias, C. 2014. "Ideal Moment of Crop in Chloris gayana cv. Callide." Pastures and Forages 3: 2.

[37] Strickland, R. W. 1971. "Seed Production and Testing Problems in Tropical and Subtropical Pasture Species." Proc. Int. Seed Test Ass. 36: 1.

[38] Padilla, C., and Febles, G. 1976. "Determination of the Ideal Moment of Crop of the Seed of Grass of Guinea (Panicum mMximum Jacq.)." Cuban Magazine Agricultural Sciences 10: 725. 